Portland State University

PDXScholar

11-15-1977

\title{
Assessment of Feasibility of Proposed Bolted Connections for Tubular Structures
}

John Henry Tausch

Portland State University

Follow this and additional works at: https://pdxscholar.library.pdx.edu/open_access_etds

Part of the Engineering Science and Materials Commons, and the Materials Science and Engineering Commons

Let us know how access to this document benefits you.

\section{Recommended Citation}

Tausch, John Henry, "Assessment of Feasibility of Proposed Bolted Connections for Tubular Structures" (1977). Dissertations and Theses. Paper 2610.

https://doi.org/10.15760/etd.2604

This Thesis is brought to you for free and open access. It has been accepted for inclusion in Dissertations and Theses by an authorized administrator of PDXScholar. Please contact us if we can make this document more accessible: pdxscholar@pdx.edu. 
AN ABSTRACT OF THE THESIS OF John Henry Tausch for the Master of Sclence in Applied Sclence presented November 15. 1977.

Title: Assessment of Feasibility of Proposed Bolted Connections for Tabular structures.

APPBOVED BY MEMBERS OF THE THESIS COMMITTEE;

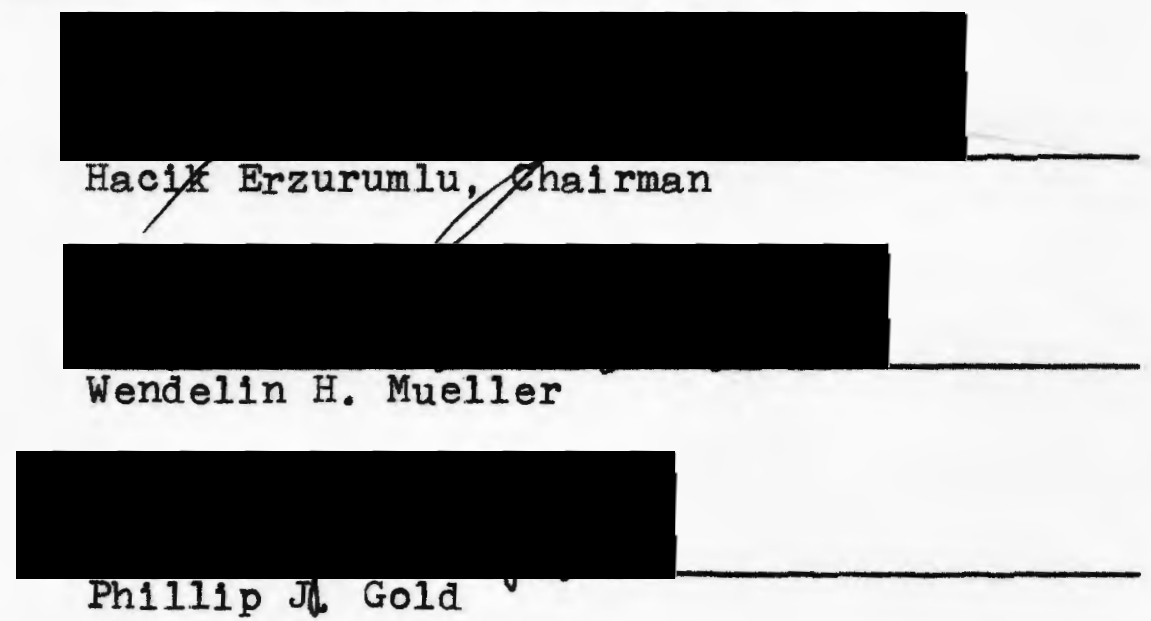

The search for new and additional sources of energy-from sun, wind, waves, and ocean currents--is necessitating the development of structures in the open environment of the oceans as well as on land. The advantages of round or tubular members for use in such structures are shown; and to avold the uncertainties of relded joints, two bolted connections are proposed and their feastbility explored. A model was designed and made to resolve the problems 
2

presented by size, fabrication, and code requirements, and considerations that influence analysis have been pointed out. A typical computation is included to illustrate the application of current design methods to the proposed bolted connections.

Based on these investigations, the two bolted connedtons are considered feasible for tubular structures both in protected areas and under severe weather conditions. 
ASSESSMENT OF FEASIBILITY OF

PROPOSED BOLTED CONNECTIONS FOR TUBULAR STRUCTURES

by

JOHN HENRY TAUSCH

A thesis submitted in partial fulfiliment of the requirements for the degree of

\author{
MASTER OF SCIENCE \\ in \\ APPLIED SCIENCE
}

Portland State University

1977 
TO THE OFFICE OF GRADUATE STUDIES AND RESEARCH:

The members of the Committee approve the thesis of

John Henry Tausch presented November 15, 1977.

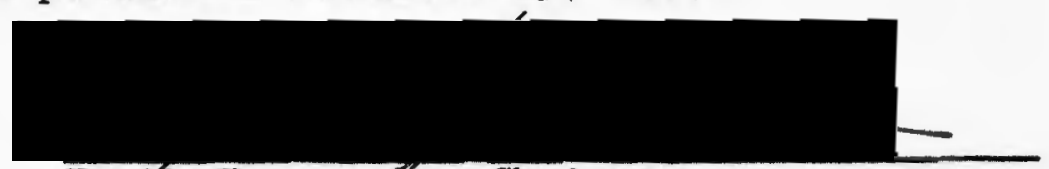

Hagti Erzurumiu, Chairman

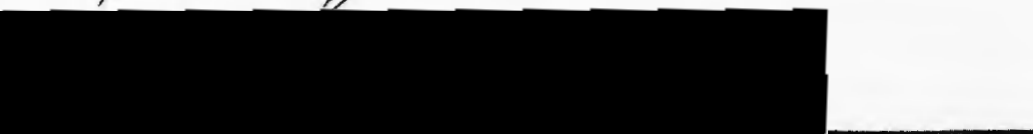

Weñdelin H. Mueller

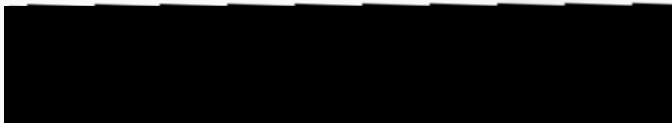

Ph1111p U Gold

APPROVED,

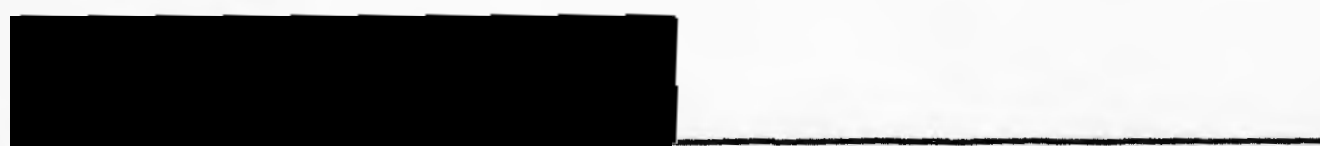

Fred M. Youps, Head, Department of Engineering and Applied Selence

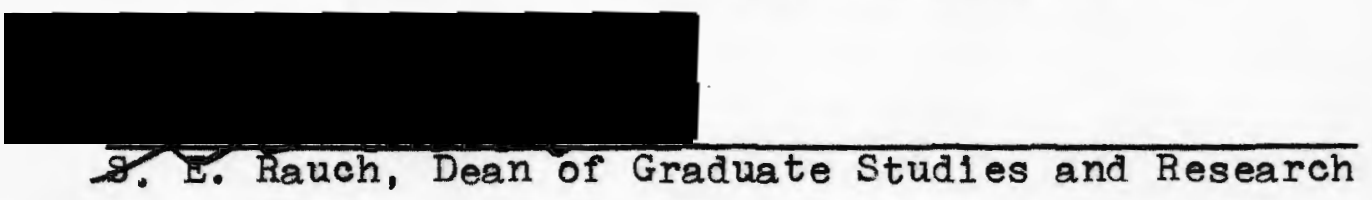




\section{ACKNOWLEDGMENTS}

The author wishes to express his appreciation to Dr. Hac1k Erzurumlu, whose guldance, Views and comments, based on his wide experience in structural engineering and design, have been invaluable. Gratitude also goes to Dr. Wendelin H. Mueller for his suggestions, help, and comments; and to Dr. Phillip J. Gold for his critical review of the thesis. Speclal thanks are due Professor Theodore C. W. Grams, Director of Processing Services, for his advice regarding the photographs and reproduction of the plan drawings; and Mrs. Donna Mikulic of the Department of Engineering and Applied Science for her competence and patience in answering many questions. Finally, the author wishes to thank his wife, Elizabeth, for her untiring help in editing and typing this thesis. 
TABLE OF CONTENTS

PAGE

ACKNOWLEDGMENTS

LIST OF FIGURES . . . . . . . . . . . . .

CHAPTER

I INTRODUCTION ............. . I 1

II TUBUtaR STRUCTURAL MEMBERS . . . . . . 3

III BOLTED CONNECTIONS FOR ROUND TUBULAR MEMBERS ......... 6

Two Proposed Bolted Connections... ?

The Design and the Model ..... 9

Tubular Bolted Connection with

Prefabricated Bracket ...... 12

Flrst Method of Attachment . . 20

Strength of Threaded Insert and Regular Nut Compared

Second Method of Attachment . . 22

Tubular Bolted Connection with

Adapter Piece........ 2 26

IV FATIGUE AND STRESS CORROSION . . . . . 36

V SUPPORT STRUCTURE FOR EQUIPMENT . . . . . 39

vi CONCLUSIONS ... . . . . . . . . . 42

REFERENCES . . . . . . . . . . . . 44

APPENDIX ................... 47 


\section{LIST OF FIGURES}

1. T-Bracket Connection ........ 10

2. The Model Unassembled ......... 14

3. The Model Assembled......... 14

4. Installation Device......... 23

5. The Tapped Bar ............ 25

6. Adapter Connection ......... 27

7. Gusset Plate Connection with T-Bracket......... 30

8. Tubular Strut Flat Pressed

End Connection ........ 32

9. Tubular Member Slotted

End Connection ......... 33

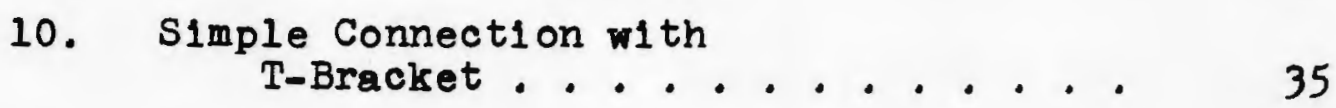

11. Types of Trusses and Frames...... 41

12. Tension Member with T-Bracket..... 48

13. Load Rotation Diagram ......... 49 


\section{CHAPTER I}

\section{INTRODUCTION}

All indications are that the need for energy is unabated and rising. The quest for new and additional sources of energy is underway throughout the world. Deposits of minerals, gas, and oll on land--once considered inexhaustible--are being depleted at an alarming rate.

ocean exploration has shown that large deposits of minerals and fuels are located beneath the seas. Today much is belng done to develop ways and means of obtaining access to these deposits. Exploration, drilling, and mining for these resources proceed from platforms fixed or floating at the proper locations in our oceans. Vessels for deep sea mining are in the derelopment stages, and a few are already on location.

Proposals are being made to locate platforms in the open environment of the oceans which will have mounted on them wind generators, solar concentrators, and equipment to harness the energy avallable from the waves.

The ressels and platforms currently in use require a multitude of special support structures that are designed and bullt to meet individual needs. The platforms themselves employ structural members of both conventional and 
tubular section. Almost all are rigid or semirig1d rames with welded or bolted joints.

Th1s paper w111 consider structures suggested for the support of equipment employed for the generation of energy from the sun, wind, waves, and other sources. It is proposed:

(1) To review members of round or tubular section used in these structures.

(2) To explore the feaslbility of tubular connections of bolted design. 


\section{CHAPTER II}

TUBULAR STRUCTURAL MEMBERS

Standard structural sections employed in frame construction include the H- and I-sections, angle combinations, and the tube or pipe. The industry can currentiy offer tubes of both round and rectangular configuration, which offer similar section characteristics.

Square tubing is produced by at least three manufacturers in the United States, and foreign tubing is stocked by some warehouses. The Welded Steel Tube Institute (1) lists cold formed square tubes in ranges from $2^{\prime \prime} \times 2$ " to 16" x 16", w1th thicknesses from $1 / 4$ inch to $1 / 2$ inch depending upon the tube size. In the past trenty years lack of availability has made itself felt in sizes from 6 inches up. Orders in the larger sizes had to be of sufficient tonnage and required six months for delivery. This can be a very real ilmitation in a given design effort, where time is limited.

Round tube and pipe is manufactared by every industrialized country around the globe. Nominal sizes from the small to about 24 inches in diameter are readily avallable from the larger warchouses in principal cities of this country. Nippon Kokan $(2,3)$ and Bethlehem Steel 
(4) are tro suppliers.

In the author's experience in shipbuilding and other heary construction, it was demonstrated that structural members fabricated of round cross-section are desirable, if not mandatory, for the following reasons:

(1) They offer less resistance to flow of wind and water as compared to the square or angular section.

(2) Maintenance (repair and painting) is easier and less costiy. Concealed areas are ellminated, making inspection more reliable.

(3) De-icing (hot conductor method) is almost automatic.

(4) The round tube or pipe is designed to be a conductor of fluld under pressure. This requirement calls for proper attention in the selection of materials and methods of manufacture. Service requirements act in the interest of quality control and reliablilty.

(5) The round tube and plpe is universally avallable.

The mast, the tripod, the quadrupod, and similar structures on modern vessels are now mostig constructed of round tubular members. They are fabricated and relded on shore under controlled conditions--that is, supervision and inspection are properiy carried out. 
The advantages in the use of round tubular members on ships apply equally to fixed and waterborne platforms for varlous other services at sea and also for land operations.

Structures that will at. times be 1 mmersed in seawater may involve materials other than medium- and highstrength steels. In ship design extruded aluminum is regularly used for tripod masts and frames that must be 11ght and anticorrosive. Research 18 bolng conducted both in this country and abroad in the development of equipment and means for obtaining energy from the waves. Stainless steel arms and frames made of tube are making their appearance in equipment now belng proposed.

Factors such as economy, design, fabrication, serv1ce, and maintenance are part of the overall considerations. Therefore, round tube in nominal sizes, standard, extra strong, and to schedule number, is employed in these investigations. 


\section{CHAPTER III}

BOLTED CONNECTIONS FOR ROUND TUBULAR MEMBERS

The bolted connection for round tube structures is recommended for the following reasons:

(1) Bolt fasteners are economical and reliable.

(2) They can be obtalned in several grades of strength to meet various design requirements.

(3) They are stocked in the several grades in most communities throughout continental United States and also in the larger cities of the world.

(4) Bolting is faster in erection. McCormac (5. p. 232) points to time savings realized if bolted connections are used instead of relded connections. Conn (6) says, "It takes over 12 months to train a certified relder but only 15 minutes to train a man to tighten a nut correctly."

(5) Welding and fabrication in the field always lead to allgnment problems. In producing some of the tallormade joints in the fleld, and also in the shop, the necessary fitting and adjustment is time-consuming and can be wasteful of materlals, and for these reasons is costly. 
(6) Misalignment can lead to uncertain load distribution and stress concentration.

(7) Bolted connections lend themselves better to maintenance. Bolts can be replaced. Larger bolts can be installed if required.

(8) Fleld relding can lead to poorly made jolnts if accessibility is limited. Also, welding and inspection on structure that is not stable or is subject to high winds can be costly and reldIng standards can be overlooked.

(9) Welding cracks are eliminated. These cracks, produced by improper preheating or lack of preheating, may at first not be evident but can become troublesome later in the I1fe of the structure. Cracks are stress ralsers and therefore can lead to structural fallure.

(10) Bolted structures can be analyzed for stress and also for $\nabla 1$ bration with more certainty by methods nor avallable.

These points are borne out in several technical publications $(6,7,8)$.

\section{TWO PROPOSED BOLTED CONNECTIONS}

Two bolted connections for tubular structures for both marine and land installations are here belng presented. In developing the fabrication and design features 
of these connections, ease of manufacture, economy, and availability are important factors.

At the outset 1 should be stated that the designs to be developed should meet the requirements of sound structural principles and also be in agreement with the basic and applicable requirements of the American Inst1tute of Steel Construction (AISC) and American Welding Soclety (AWS). However, certain limitations are usually recognized which are related to manufacturing, economics, service requirements, etc. McGuire (9, p. 787) states:

Most connections are highly indeterminate, with the distribution of stress depending upon the deformations of the fasteners and the detall material. Local restraints may prevent the doformation necessary for desirable stress redistribution. For these reasons a purely theoret1cal approach to connection problems is always difficult and often nearly impossible.

It has already been pointed out that the structures to be served here will find application in the support of machinery and equipment that will be required for the generation of energy from the sun, wind, and waves or ocean currents. The proposed bolted connections would apply to structures generally, such as towers, frames, trusses, etc.

To provide a fixed base from which to proceed with the detall discussion, it is necessary to derine structural members in regard to size, materials, and reliabil1ty. The usual practice of referring to pipe standards long in use is adhered to, that is, classification as standard, extra strong, and double extra strong pipe or 
tube. Sizes which fall into the schodule classification are also included. Th1s allows selections to be made based on nominal dimensions with outside diameter and thickness specifled. In regard to materlals and physical properties, a wide selection is possible.

The range of sizes here under consideration will start with 5 inches and terminate w1th 24 inches, and w111 include intermediate sizes in this range. The usual methods followed in structural work regarding detall, fabrication, materials, etc., are here also adhered to.

\section{THE DESIGN AND THE MODEL}

The general design of the bolted connection is shown In Figure 1. As this study progressed it became clear that an actual model would be required in order to resolve the problems presented by size, fabrication, and code requi rements.

The plpe of smallest diameter in the range estabI1shed was chosen for both the inltial design and the model for the reason that it has the greatest curvature and any mismatch between the outside radius of the structural member and the inside radius of the T-bracket flange would be most pronounced.

Space and clearance considerations were also factors in selecting the model size.

The maximum curvature or smallest tube size was 


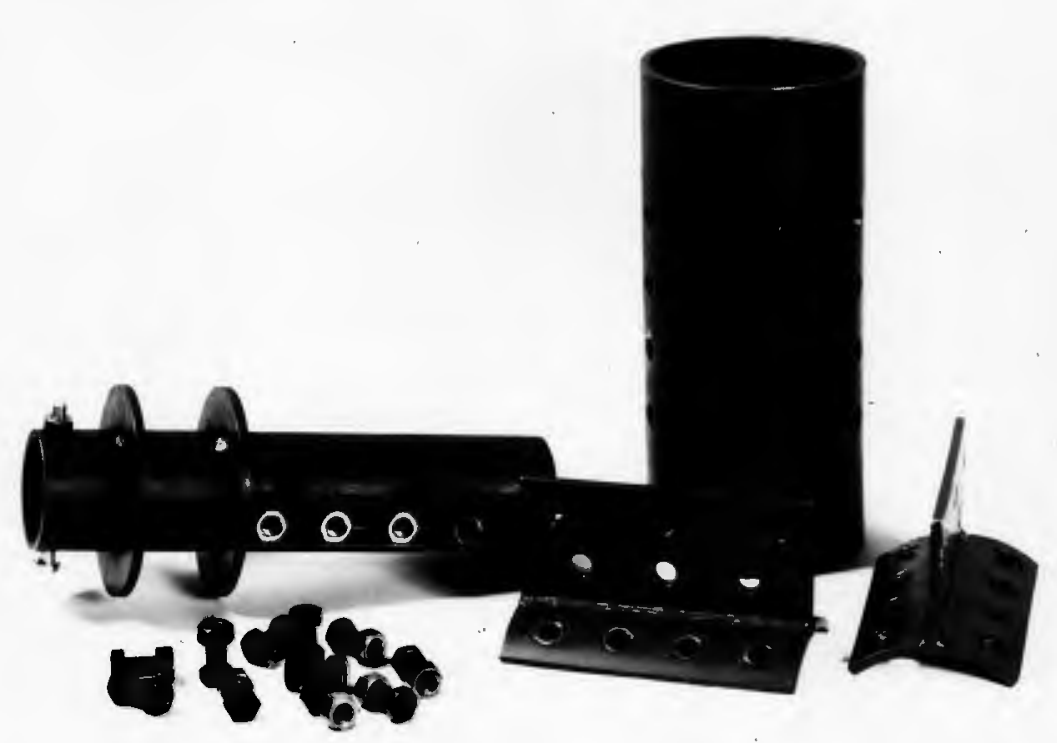

Figure 2. The model unassembled.
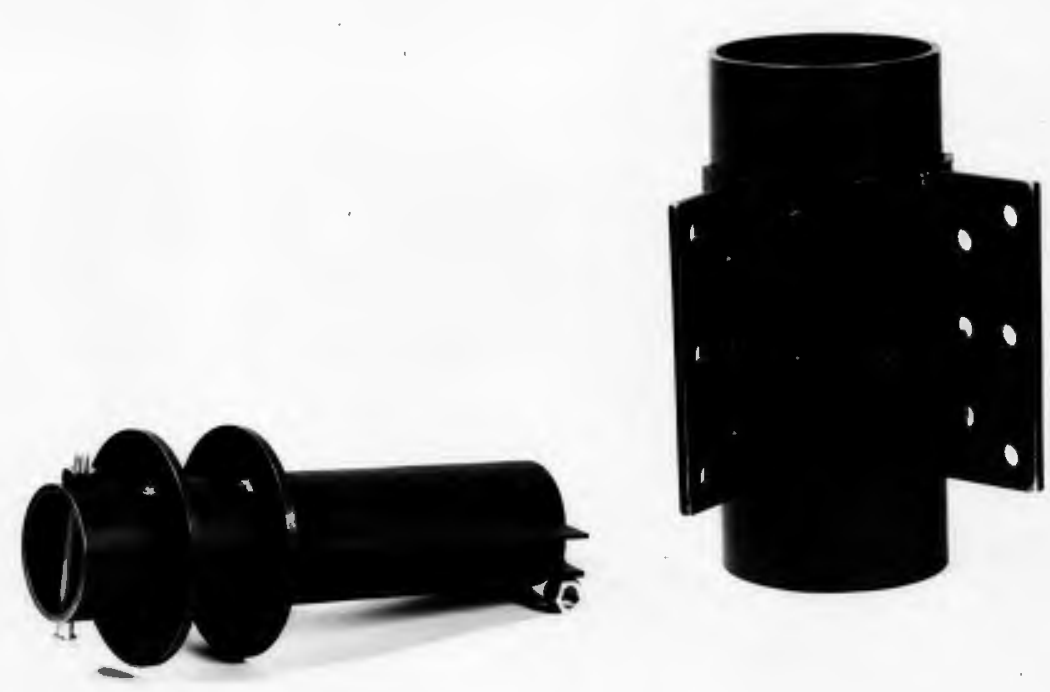

Figure 3. The model assembled. 
T-bracket to the outside radius of the tube, in the example lllustrated in Figure 1 and for the model the lower $11 \mathrm{mlt}$ or 5 inch tube was chosen as the size with the smallest diameter and the maximum curvature.

The material used in making the model or prototype is structural type tubing to American Soclety for Testing Materials (ASTM) specifications, A501, $F_{y}=36 \mathrm{ks1}$, as given in the AISC Manual (10, p. 1-101), and the flanges of the T-brackets are fabricated of tubling of the same material and size.

The steps in the fabrication of the T-brackets can be followed by reference to Figure 1. The bracket is shown to accommodate two rows of four bolts. A section of tube is cut to the length of the required flanges. The selected length, in this case 7 1nches, is divided parallel to the axis of the tube into four equal sections. These quadrants are marked to show up on the section face at each end of the plpe. These divisions are carrled down the outside of the tube section, dividing the outer surface of the tube into four equal curved areas. These vertical lines can then be fine-burned. However, in making the model it was found that the cuts could be made just as well on an avallable band sar.

It should be noted here that the curved flange was produced in a small shop with regular equipment and labor, including the author's. The entire operation of making the 
saw cuts took about fifteen minutes. The author performed the layout work himself for the reason that no material could be spared. The maximum diameters were located on the end face of the tube with a machinist's divider, a center punch, and other simple means. For a check, the maximum diameters were brought to the other end of the plpe section by means of the parallel division lines mentioned above. These lines located the four maximum diameters to less than $1 / 32$ of an inch.

The same procedure rould hold for manufacturing the flange of the T-bracket if the primary tube is fabricated of rolled can sections instead of regular or special pipe. Plate of required thickness and width of flange is rolled into a ring similar in shape to the can. The inside radius is adjusted to exactly match the outside radius of the fabricated pipe. The open tube section is then cut into quadrants required for the T-brackets.

Detall calculation may show that thicker flanges are required in a given design. These could then be fabricated from sections of thicker tubing. Also, they could be rolled and formed from thicker plate of width equal to the length of the brackets needed. The rolled rings are marked parallel to the principal axis of the ring, then fineburned or cut by band-sewing into the required section sizes.

The gusset is jolned to the curved flanges by means 
of a full penetration weld. The flat gussets are of structural grade steel, and the joint for the weld was prepared about as specifled for welded joints by the AISC Manual (10, p. 4-137, TC-U9a, Double-J Groove).

All drilling was to be done after welding. The curved faces on each end of the flanges were halved and clearly marked by center punching. These marks were to be used for the location of the gussets, indicated also in Figure 1. In the case at hand, the gusset and flange clamped easily together by means of two large C-clamps after the proper alignment with the curved flange was obtained (punch marks at half sections of the curved surfaces). All welding was then performed by a qualified welder, using $\mathrm{E} 70 \mathrm{~T}$ electrodes.

After the gussets were tacked lightly and checked for verticality (with slight corrections made on the spot), a second set of tacks went into place, with no need for correction of verticality. The weld was then made. Also, each end of the welds was sealed to prevent any ingress of mo1sture.

McGuire (9, p. 863) mentions the possible flange distortion that could be produced at a T-connection. While this did not occur, any uplift would have bettered the adjustment of the inside radius of the flange to the outslde radius of the tube.

In placing the T-bracket flange on the outside of 
the tubular section, a gap of a little less than $1 / 16$ inch could be measured. Such a gap is considered unacceptable, although the pull of the attachment bolts rould reduce this gap to a certain extent. The following procedure gave a satisfactory match by reducing the gap to zero at onehalf flange width and to less than $1 / 32$ inch at one-quarter flange width. The T-connection was placed in a vise with the concave surface of the flange facing upwards. An oxyacetylene torch was played along the center of the concave flange; heat was applied up to the plastic range indicated by a bright white color; the T-bracket was then removed from the $\nabla 1$ se and placed on a plece of tube of the same dameter as the one to be matched. The center of the Tbracket, now in or close to the plastic range, was struck several hammer blows and the adjustment was made. When cold, measurement revealed that the $1 / 16$ inch gap at half point was eliminated, and at quarter points the clearance was close to $1 / 64$ inch. In a later discussion of Fatigue and Stress Corrosion reference will be made to this gap, If it occurs, and to a method of preventing ingress of molsture to the body of the bolt.

In the model shown in Figure 3, the bolts are torqued as required by the AISC specifications on structural joints using ASTM A325 or A490 bolts (10). W1th these loads applled, the slight gap at quarter points vanished entirely. 
With the flange in position and attached, the next step is to locate the bolt holes on the convex side of the T-bracket from dimensions aval lable from the detall plan. Parallel Iines are scribed, spaced, and prick-punched on the flange at each side of the gusset. Although drilling may appear to be involved and roundabout, it really is not.

The T-bracket is placed on the table of an ordinary dr111 press sidewise against a fixed stop; the side of the flange to be drilled is blocked by a piece of steel to the helght required to produce the necessary radial direction, then flxed. No special j18 is needed, but would probably be used in a production setup. Also, the arrangement allows motion sidewise, to slide the T-bracket under the drill as required. The holes can now be drilled. Again, it may appear involved to produce the flat washer surfaces that match those of similar dimensions under the bolt head or on the sides of mating nuts. This is done with the same setup as used for drilling the holes. This bearing surface is produced by a counterbore or circular cutter, into the center of which the drill for the drilling of the bolt holes is mounted. After a bolt hole is drilled, the counterbore produces or mills the surface for the washer faces of elther the bolts or the nuts. If this equipment is not avallable, the same operations can be accomplished in several steps with conventional tools. 
Earlier in discussing the matter of locating lines and points of reference on the tube member, the T-bracket locations were also fixed. These flxed locations are now used in conjunction with the finlshed T-bracket, to be used as a template, from which to take the locations and drill the holes in the tubular members.

The entire fabrication procedures described above for the T-brackets 111 apply to both methods of attachment detalled in Figure 1 as the First Method and the Second Method.

\section{First Method of Attachment (Figure 1)}

Instead of employing through bolts and nuts for attachment of the T-brackets to the primary tubular members of a given structure, it is proposed that the bolts be threaded directly into the structural tuber that is, nuts are omitted and replaced by the tube as the second part of the fastener. The question arises, Hor reliable is such a connection when compared with the usual through bolt arrangement?

To thread the tube, the same setup is used as for drilling the holes for a through bolt design, the difference being that the tap drill replaces the drill required to produce the clearance holes for the through bolts. After these holes are drilled, the drill is replaced by the tap for the required bolt size and threads specified, the threaded holes being produced on the same machine tool 
with a proper change in cutting speed.

Strength of Threaded Insert and Regular Nut Compared.

The $\mathrm{A} 325$ bolt and nut are used as a base for comparison with the threaded insert shown in Figure 1. The AISC Manual (10, p. 5-195) specifies the initial fastener tension as 12,000 lbs., to be produced by a predetermined torque, or the turn-or-nut method. This method was used in the assembly of the model, Figure 2 and Figure 3.

When a threaded insert takes the place of a throughbolt design, the tube wall should have strength properties equal to or better than the nut for the bolt size under consideration. By deduction, any insert must provide sufflclent thread depth, that 1s, depth equal to or better than that provided by the standard nut thickness. A general rule for the thickness of a nut is that it should be at least equal to the nominal diameter of the bolt employed. (Under certain circumstances, nuts of lesser helght than standard can be effectively used, as in many special applications.) In the case here considered, where a $1 / 2$ inch nominal bolt size is used, the rule would specify that the tube thlckness be at least $1 / 2$ inch. The 0.258 inch in the design in Figure 1 (First Method) is insufficient. However, the tube used in Figure 1 was of standard size and with $F_{y}=36 \mathrm{ks}$ material. If extra strong tube or pipe, or a doubler, is provided in the construction and perhaps a higher quality material, then the proposed 
design should after analysis be entirely satisfactory.

Later, in the discussion of the adapter design, the threaded insert 111 again be touched upon and shown to have considerable merit since ample thread depth can be provided.

Second Method of Attachment (Figure 1)

The bolting arrangement shown in Figure 1 as the Second Method employs through bolts and is to conform to the detall specifications for bolted joints as required by the AISC. Here the threads and assoclated nuts are enclosed entirely by the tube, away from the detrimental influences of the elements. These standard fasteners can be installed in several ways. Two means of installation are described here; others will suggest themselves to the reader.

The detall sketch of an installation tool is shown in Figure 4, with the nuts located in a small channel plece ready for installation in the structure, with nut spacing taken from drawings provided. To place a group of nuts behind mating holes in the primary member of the structure to be assembled, the tool is lowered down the tube or, if the tube is on its side, slid in sidewise. After the holes in the tube are aligned with the nut centers, the bolts are inserted from the outside and torqued as required in the detall specifications mentioned above. After installation of the nuts, the tool is remored. 
The steps just enumerated were followed in the assembly of the model fabricated from the detall draving Figure 1. The two photographs show the connection and 1 ts parts, Figure 2 Unassembled and Figure 3 Assembled. Care was taken in the production of both the steel model and the installation tool that average shop practice prevalled. It can also be sald that no great precision was required, at least, no more than that which would be practiced by the average fabricator.

Instead of a channel piece with nuts inserted, a tapped bar can be strapped to the installation tool. Such a tapped bar is shown in Figure 5, installed in the structure. The spacing of the tapped holes is determined from the dimensions shown on the structural plan.

The threaded bar can also be placed on and strapped lightly to a wooden reach rod by means of electrician's tape. The installation tool with bar or bars is slid into place and the threaded holes are picked up from the outside by insertion of the mating bolts. The bolts are taken up and torque applied as required by the specifications and similar design requirements.

Th1s bolting design is considered to conform in all respects to the specifications in the AISC Manual (10). 

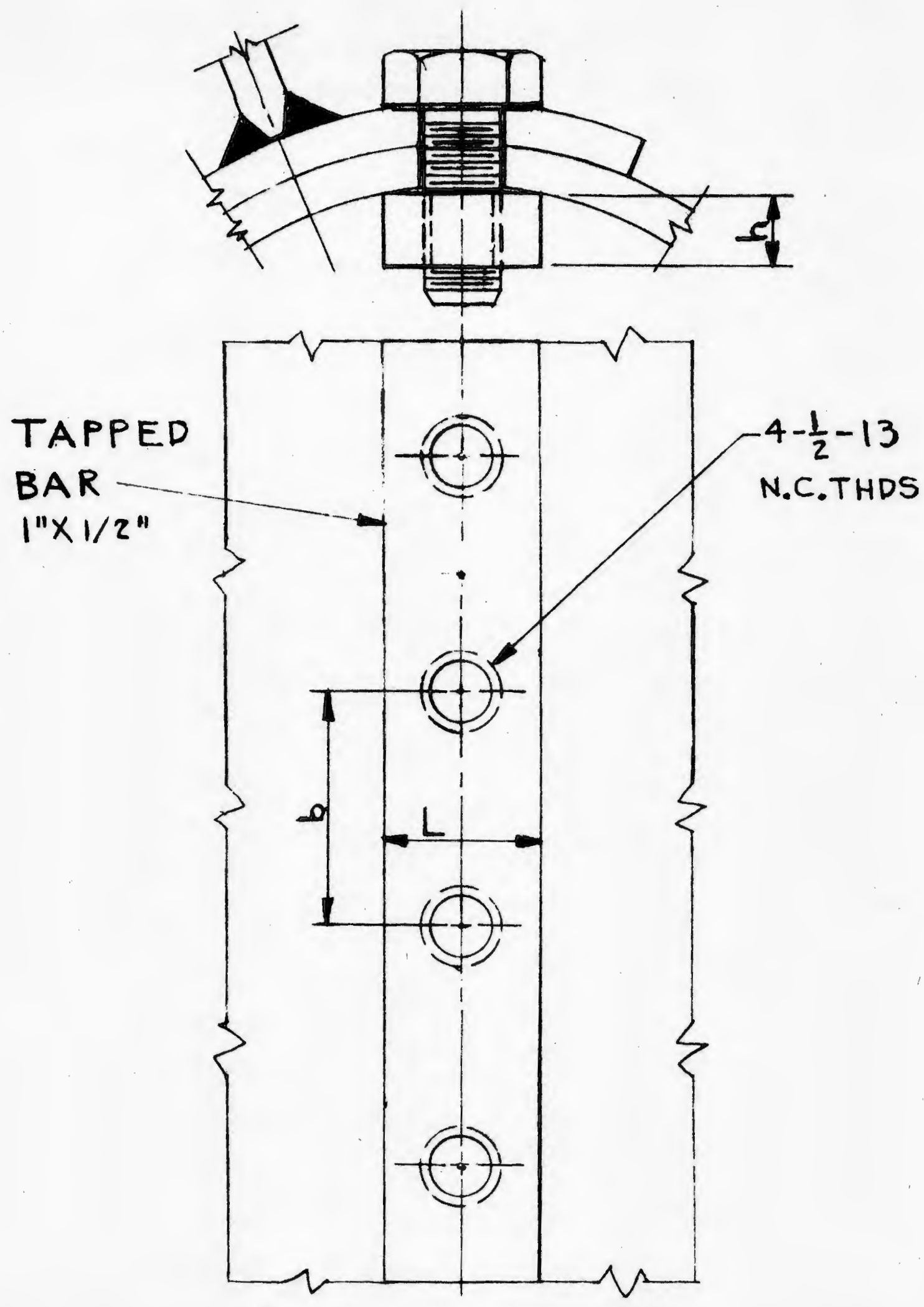

Flgure 5. The tapped bar. 
TUBULAR BOLTED CONNECTION WITH

ADAPTER PIECE

The detail design and the assembly of components of this connection are shown in Figure 6 . The adapter or saddle shown provides the change from round to flat in order that structural members of varlous sections can be used. Again, the size range 5 to 24 inches primary tube dlameter will be adhered to.

Since the parts that make up the complete connection are standard structural 1 tems, no model has been constructed to full size, as was done for Flgure 1. However, a smaller model using 2 inch standard pipe size was constructed by the author in order to assemble the information necessary to discuss the design shown in Figure 6.

The materlal suggested for any given design would be cast steel, although the adapter can be rolled of steel bar stock, provided that the order is of sufficlent size or tonnage to make it profitable to the m11l. The re-rolling process proposed is to take bar stock of sufficient size, heat and re-roll by means of contour rolls to give the radius desired to match the structural tubes to be employed in the structure. To the author, this procedure has 11m1 ted application at the present time, therefore the cast steel adapter is discussed here in detall.

Once a tube size or tube sizes are selected and the other details of a structure are determined, it is a simple 
matter to provide the principal dimensions of the adapter to be used in the assembly. A pattern must be made. For the cross-section see Figure 6, which is for the 6 inch size shown, although these comments apply to the entire range of the tubes considered.

The author finds that the cost of such a pattern is insignificant. It w1ll be noticed that no loose or secondary pleces are required for the pattern. In fact, these simple patterns can be made by any small pattern shop or by the fabricator himself. The needed castings can be made by small job foundries that produce steel castings. The parting line for cope and dras will be at the flat of the pattern. The plece is cast th the curvature down. The castings made from the author's pattern came out sound and were flat and true. The curvature (to shrinkage scale) matched the plpe selected very closely. The steel used was to ASTM specifications but not specially selected for the service intended.

As in Figure 1, the design here considered, Figure 6 , shows for attachment both the through bolt, the Second Method, and the tube and adapter threaded, the F1rst Method. The fastener indicated as the Second Method w1ll be installed as was suggested in the installation procedure for the T-bracket design. Where threading into the wall of the tube was not consldered satisfactory in the Tbracket design, it is considered entirely satisfactory when both the steel adapter and the walls of the tube are 
threaded.

In Figure 6 the welding of the adapter to the tube is ent1rely satisfactory, first, from a strength point of view; and secondly, because any molsture that might find 1ts way into the contact area between the adapter and the outside of the tube is ruled out since the weld is continuous at the sides and top and bottom.

The designs considered here concern themselves with the bolting, assembly, fabrication, and economic considerations of the actual connections. In the discussion of the design proposed in Figure 1 it was mentioned that the Tbracket would provide the desirable effect of strengthening, and as a result of this giving additional rigidity to, the joint. The adapter design proposed here (see Figure 6) also provides additional rigidity to the connection, which can be varied to the requirements of a given structure. This desirable feature will not be made a part of this investigation for the reason that the designs proposed here will, among others that will be developed in the future. need to be evaluated in regard to stress and load transfer, which will require further research.

Several typical connections are shown in the sketches following. In Figure? several tubular members come together at a nodal point in the structure. It should be mentioned that the open construction provides for easier 


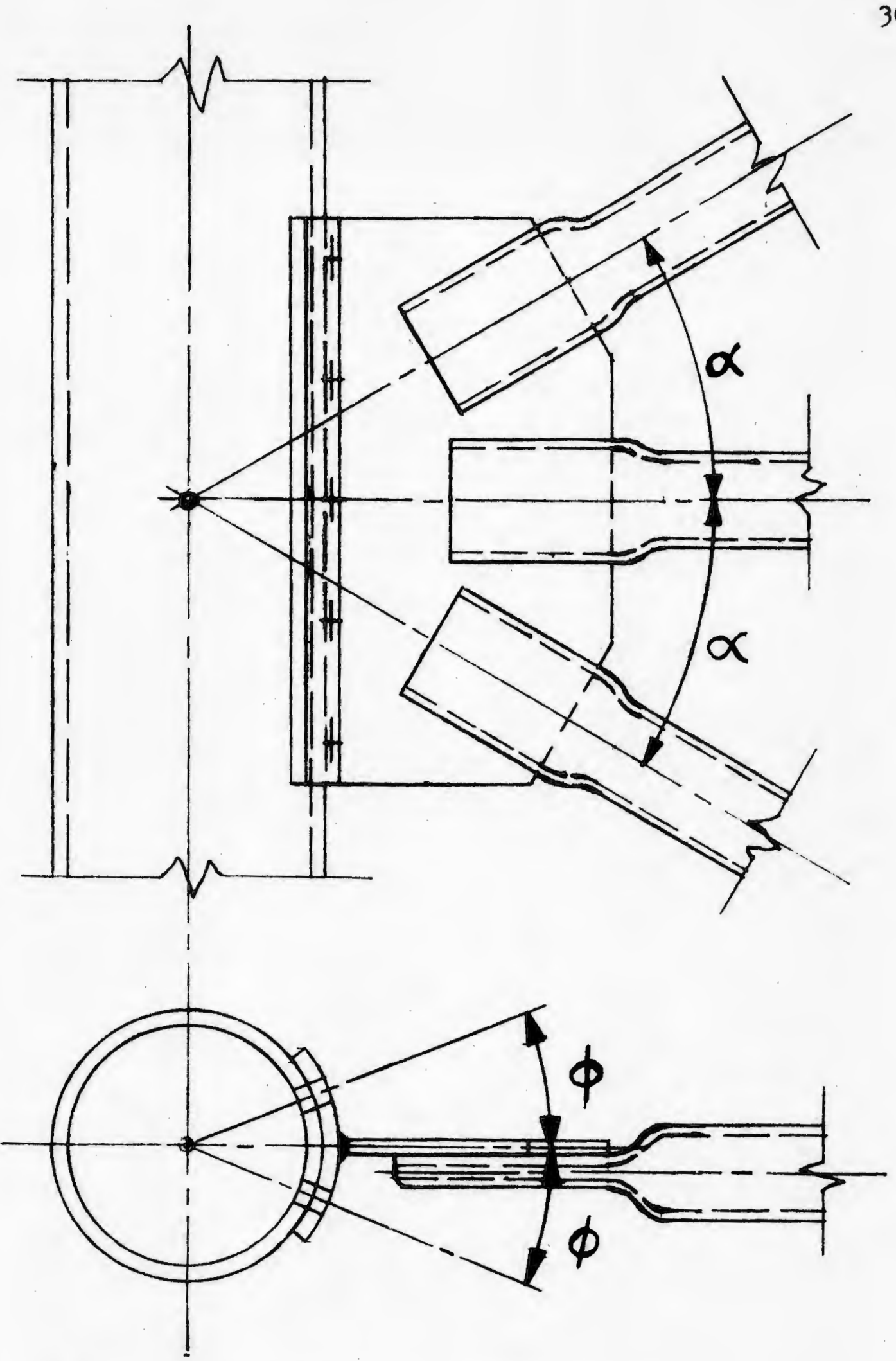

F1gure 2. Gusset plate connection with T-bracket. 
malntenance for the reason that all parts are more accessible. Any bolting can be reached with standard tools. The three members coming into the joint and shown also as tubes are elther bolted to the gusset or welded to the mating member as the design requires.

Two methods of attachment for the three tubular members coming into the joint are indicated. The one shown in Figure 7 and presented in detall in Figure 8 is produced by heating the tube end in a portable induction heater. The heated tube is deformed by a press, either without or by means of a latch die, to its final shape. In the design of a structural member with this type of flat end connection, it should be mentioned that a certain amount of eccentricity is unavoldable. This eccentricity is indicated by the letter "e" in the detail of the connection in Figure 8. This type of pressed end connection should therefore be employed only for members under axial load, that is, as secondary members in a structure.

In the case where a member is both loaded in the axial direction and has moment applied to $1 \mathrm{t}$, eccentricity should be absent. The design shown in Figure 9, the slotted tube, which is symmetrical and without eccentric1ty, is suitable for use as a primary member in a given structure. 


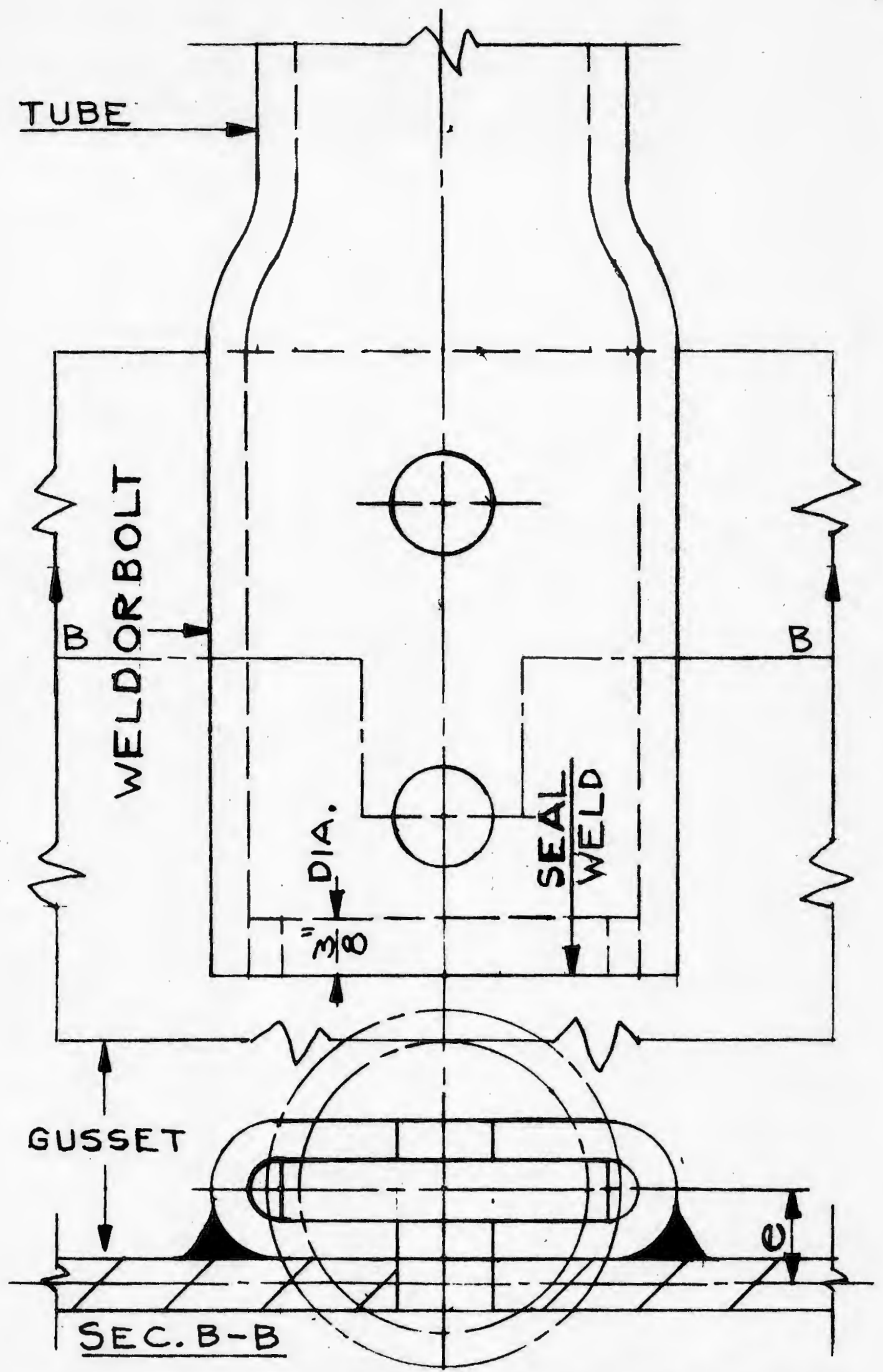

Figure 8. Tubular strut rlat pressed end connection. 


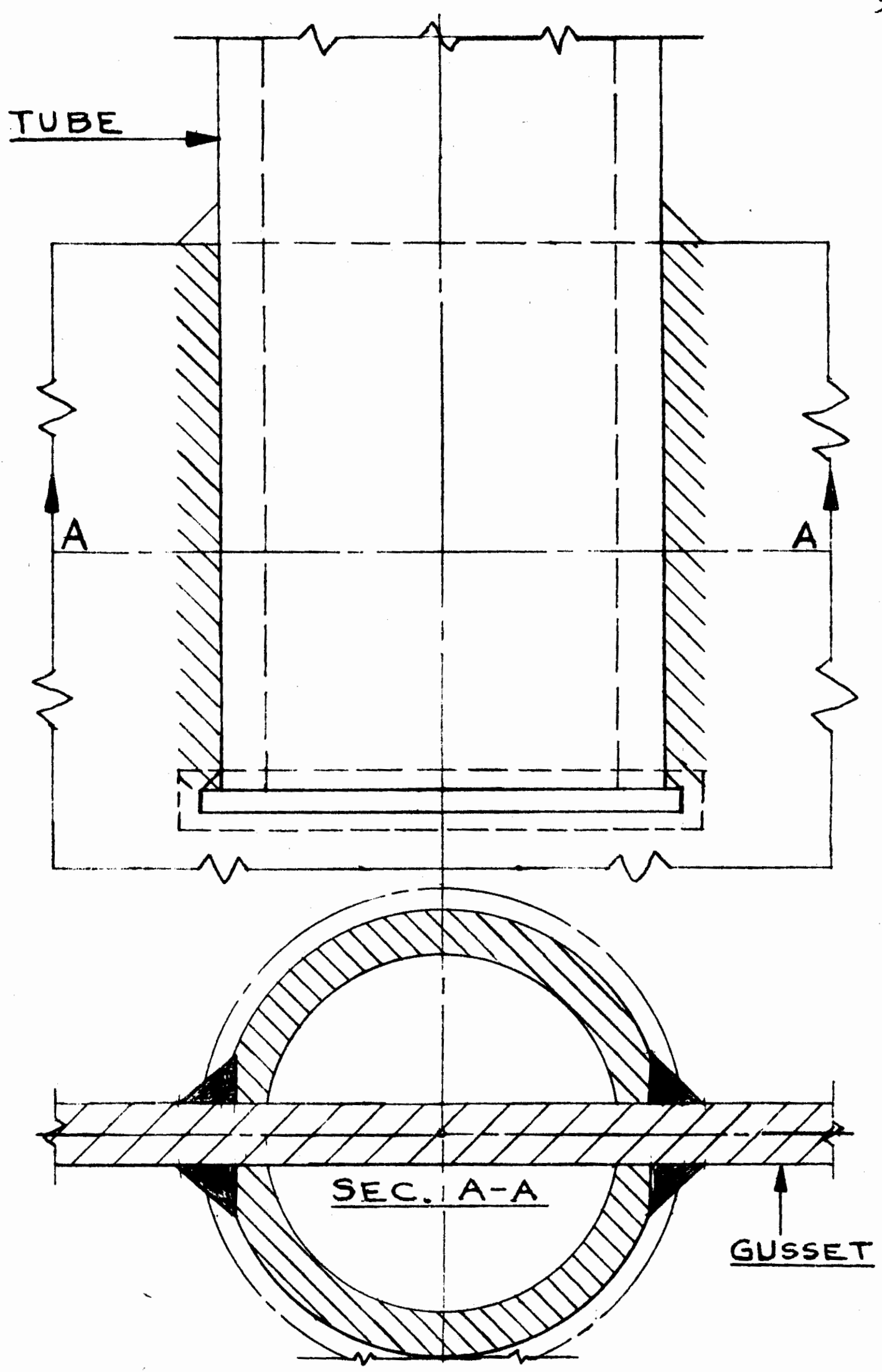

Figure 2. Thbular member slotted end connection. 
To show a light framed connection employing the Tbracket, Figure 10 is added. The individual proportions are only to indicate the relationship of the various components. Sizes shown are average in order that a better picture of the assembly may be produced. To 11lustrate the applicability of standard methods of analysis to the T-bracket design, a typical calculation is given in the Appendix. 


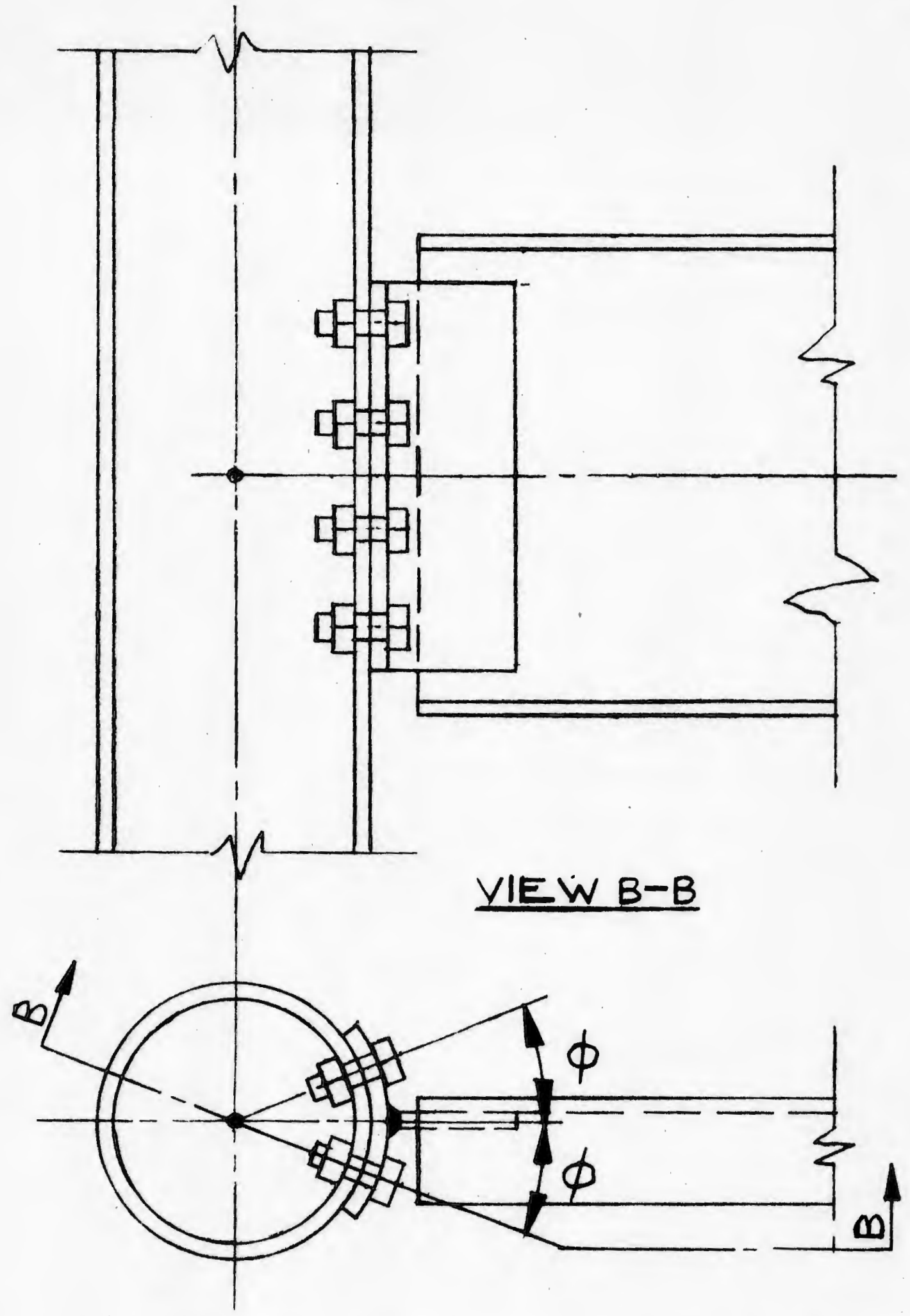

F1gure 10. Simple connection with T-bracket. 


\section{CHAPTER IV}

\section{FATIGUE AND STRESS CORROSION}

Literature past and present c1tes many cases of fallure that can be attributed to stress corrosion, the notch effect, fretting corrosion, etc.., and various combinations thereof $(11,12,13,14)$. Under consideration here Is the service 11 fe of a structure and the fatigue characteristics of the component members. The sea environment and weather conditions such as rave impact and cyclic loading, which can influence the fatigue properties of the materials employed, need proper attention.

"The first rule of design in fatigue situations is to keep stress ralsers to a practicable minimum," says McGulre (9, p. 1071). Th1s fundamental rule is at times overlooked in the design of machinery and equipment that goes to sea, such as cranes, cargo handling equipment, deck machinery, stablizers, etc. Research points to the areas that are causative, and gives certain criteria considered to be important in these situations. A useful guideline proposed for the design of structures intended for unattended fallure-free service is to reduce or eliminate the side effects produced by corrosion, questionable welds, fretting, and lack of proper quality control. Ample 
support for this is furnished in the paper entitled "Subcritical Crack Growth and Ship Structural Design" (8).

The two proposed designs, Figure 1 and Figure 6 , show several features that tend to minimize the factors that have caused fallure or malfunctioning of both machinery and structures.

First, the stress raisers, in this case the bolt threads, are placed out of reach of the elements; that is, the assembled bolt and nut are concealed on the inside of the tubular members. On the outside, sealing action is provided by placing a thin copper-nickel washer under the bolt head at the washer face.

Second, minor irregularities and any mismatch between the surfaces of the outside radius of the tube and the inside radius of the $\mathrm{T}$-bracket flange can be made molstureproof. These surfaces are palnted at assembly with a liquid sealing compound, of which several are on the market. The material familiar to the author has a urethane base, is seawater resistant, and gives satisfactory service up to about $450^{\circ} \mathrm{F}$. A useful manual describing the application and general characteristics of this sealing compound is provided in reference (15). The sealing of flat unmachined surfaces is considered satisfactory in marine practice; curved surfaces should be treated in the same manner.

A third method for molstureproofing a threaded bolt 
is to use a nut with a nylon insert at the top side of the nut. Th1s device, which is intended to provide the nut with locking means, w11 also serve as a very effective barrier agalnst molsture. Experlence has shown that bolted connections made up wh this type of nut (with insert) which were opened up after years of service gave no indication that water had found 1 ts way past the insert Into the threaded connection by way of the bolt.

The T-bracket is shown as a weldment. If the weld is accomplished under controlled conditions, that is, with satisfactory preparation of the joint and proper joint materials (electrodes), by qualifled welders, and with weldment stresses selected to be below the endurance strength for the jolnt employed, then a satisfactory serv1ce $11 f$ e can be expected (8). In regard to these weldments, fleld welding is eliminated. The relds can be fabricated in agreement with the requirements of AISC or AWS codes.

The bolted connections here presented can be analyzed by current structural procedures and are in agreement with general specifications as provided by the structural codes and the AISC, 


\section{CHAPTER V}

\section{SUPPORT STRUCTURE FOR EQUIPMENT}

What types of equipment w1ll require support structures in the accelerating search for new energy sources? Advances in technology involve new methods and new solutions to old problems.

The modern drilling platform at sea is famlilar to all. It contains supporting structures for equipment such as mooring systems, outriggers for platform positioning, radar units, blowout preventer stacks, etc. The list of new developments is constantly expanding, based on the increased demand for 011 and gas from additional sources not so readily avallable. Current exploration is being pushed far north and into much deeper water. As a consequence, new procedures and equipment must be developed.

The same applies to ressels engaged in ocean mining operations; to floating platforms proposed for nuclear power plants; and to o1l storage and refining installations. Articles in the publication Marine Technology support the view that the future will demand advanced methods of construction $(16,17,18)$.

The type of structure w11, as always, depend upon the service it is intended for. The adequacy of the 
structure is a primary requirement, especially for heavy equipment on a nonstable platform subjected to motion stresses and to wind and extreme reather conditions. Several possible structural forms are suggested in F1gure 11. Current methods of structural analysis, both approximate and exact, are provided in references $(5,19,20)$.

If the energy source sought is wind power, a1r flow w11 be a primary consideration. Here a tubular structure w1 thout cross-bracing (such as Vierendeel) might offer the least wind resistance. Groups of wind mills are being planned for certain areas, and one built under contract for ERDA is now in operation in Ohio.

In locations where severe weather, such as 1 ce and snow, prevalls the round hollow section rould provide a protective channel for power lines and heating elements.

Results from dynamic analysis are considered of greater reliability if structures are symmetrical and present simple constructional forms.

The prefabricated bolted connection described in this paper would apply to all of these structures. 


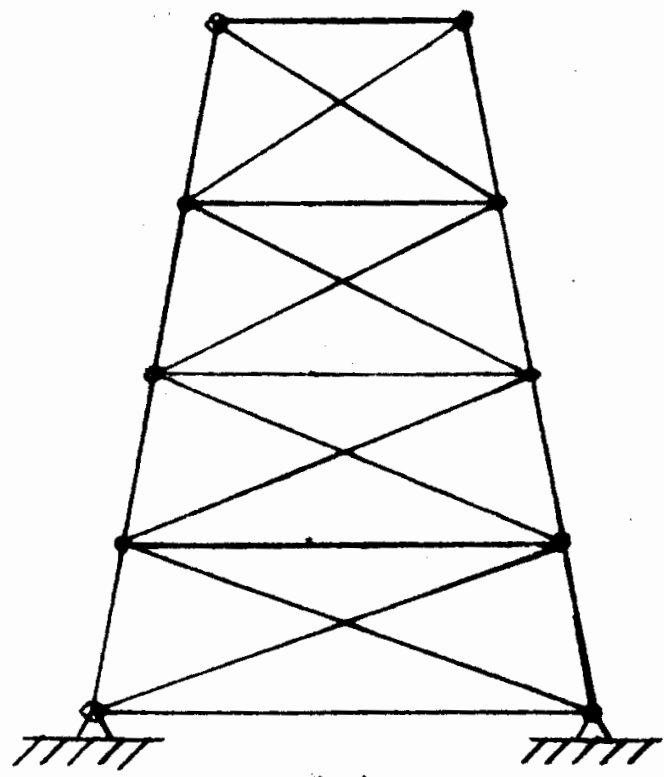

(A)

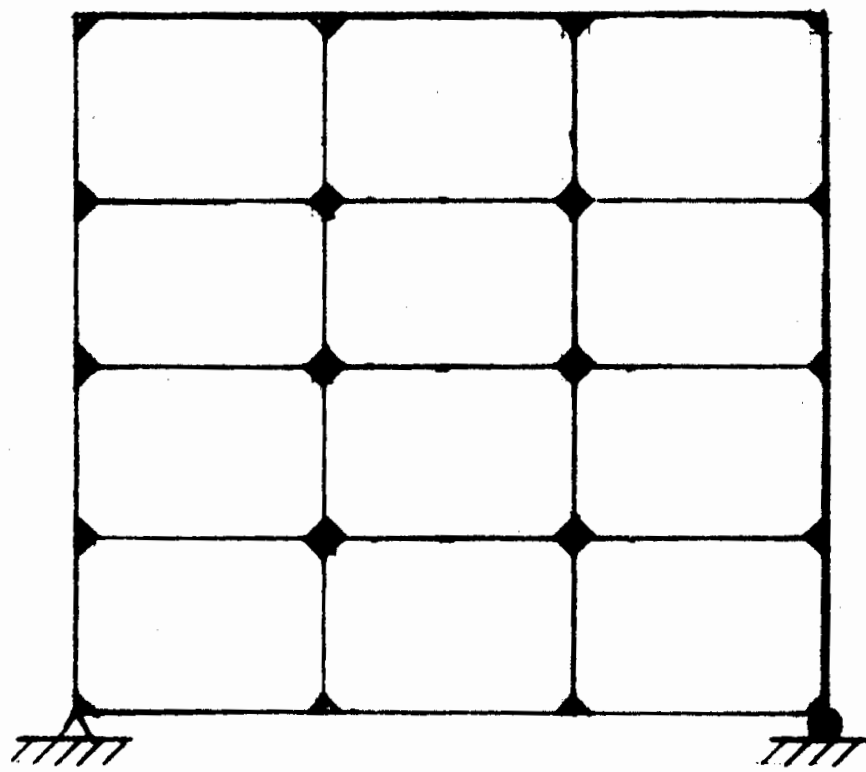

(C)

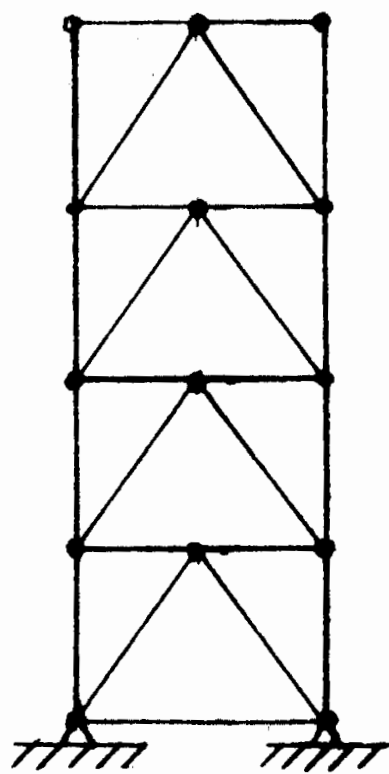

(B)

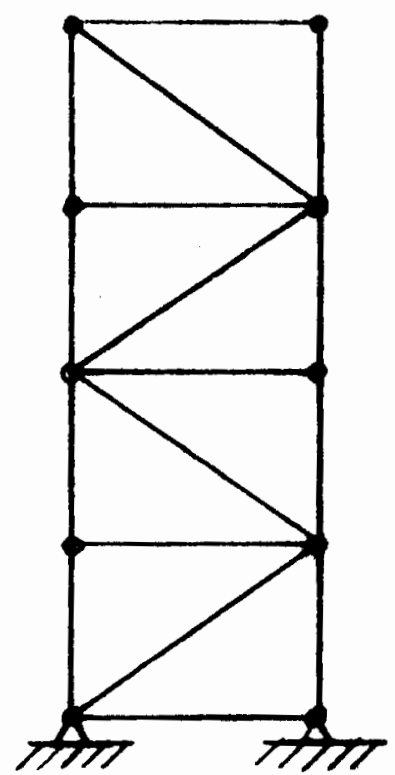

(D)

F1gure 11. Types of trusses and frames used for the support of wind power equipment and solar concentration units. (A) "X" bracing. (B) "K" bracing. (C) Vierendeel truss. (D) Warren truss. 


\section{CHAPTER VI}

\section{CONCLUSIONS}

Structures intended for the support of machinery and equipment needed for the collection and transformation of energy avallable from the sun, wind, and waves have been considered. It was shown that round tubular sections employed in these structures, whether for land or sea installations, would offer a number of advantages.

Detall design considerations that influence analysis have been pointed out, such as wave and air motion and the corrosive action of the sea.

The design has taken into consideration such features as ease and economy of fabrication, using the tools and labor aval lable to the average fabricator, satisfactory performance; and ease of maintenance of both the structure itself and the machinery it supports.

Two bolted connections have been proposed and shown to be sultable for tubular construction.

A full-size model was fabricated and assembled in conformity with standard specifications (AISC).

A typical computation is included in the Appendix to 1llustrate the application of current design methods to the connections proposed. 
43

The designs proposed have been proportioned so that adequate strength can be provided in a given application to meet the requirements of rigidity for the structural members coming into the connections.

These mutual requirements are and will be the subject of a great deal of research and development now and in the future.

Based on the investigations and information presented above, the two bolted connections are considered feasible for the structures under consideration. 
REFERENCES

1. Manual of Cold Formed Welded Structural steel Tubing. Cleveland, OnI0: Welded Steel Tube Institute, Inc., 1974.

2. NKK Specialty Tublng. Tokyo: N1ppon Kokan.

3. NKK Large Diameter P1pe. Tokjo: Nippon Kokan.

4. Bethlehem Steel 011 and Gas Line P1pe. Bethlehem, Pa.1 Bethlehem Steel Co.

5. McCormac, Jack C. Structural Steel Design, 2nd ed. New York: Intext Educational Publishers, 1971.

6. Conn, Harry. "A Real1st1c Look at Structural Fabr1cating Costs." Fasteners, Spring 1971, pp, 10-13. Cleveland, Oh10: Industrial Fasteners Institute.

7. Al1a, Bruno L., and Wheatcroft, Michael F. "Structural Materials for Marine Applications." Marine Technology, April 1976, pp. 176-183. New York: The Soclety of Naval Architects and Marine Eng1neers.

8. Francis, Philip H., Lankford, James, Jr., and Lyle, Fred F.. Jr. "Subcritical Crack Growth and Ship Structural Design." Marine Technology, April 1976. pp. 152-161. New York: The Soclety of Naval Architects and Marine Engineers.

9. MeGuire, William. Steel Structures. Englewood Cl1ffs, N. J.I Prentice-Hall, Inc., 1968.

10. Manual of Steel Construction, 7 th ed. New York: American Institute of Steel Construction, Inc., 1975.

11. Forrest, P. G. Fatigue of Metals. Oxford: Pergamon Press, 1970.

12. Nath, J. H., and Harleman, D. R. F. "Dynamic Response of Fixed Offshore Structures to Perlodic and Random Waves." Ciril Eng. In the Ocean ASCE, San Francisco Sept. 6-8, 1967. 
13. Smith, C. A. "Velocity Effects on the Corrosion Rates of Metals in Natural Seavater." Southeast Section SNAME, May 10, 1968.

14. Sellars, F. H. "Water Impact Loads." Marine Technology, January 1976, pp. 46-58. New York: The Society of Naval Architects and Marine Engineers.

15. Technical Bulletin. Montgomeryville, Pa.' Philadelphia Resins Corp.

16. Ke1l, A. H. "The Challenges of Ocean Englneering of the Future." Marine Technology, January 1968, pp. 31-38. New York: The Soclety of Naval Architects and Marine Engineers.

17. Kaufman, Raymond. "Deep-Ocean Explo1tation Technology." Mar1ne Technology, Apr11 1971, pp. 145-158. New York: The Soclety of Naval Architects and Marine Eng1neers.

18. Craven, John P. "The Naval Architect and the Design of Cities on the Sea." Marine Technology, October 1971, pp. 524-527. New York: The Soc1ety of Naval Architects and Marine Engineers.

19. Norr1s, Charles Head, and Wilbur, John Benson. Elementary Structural Analysis, 2nd ed. New York: McGraw-H111 Book Co., 1960 .

20. Kinney, J. Sterling. Indeterminate Structural Analysis. Reading, Mass.1 Addison-Wesley Publishing Co., 1957.

21. Bouwkamp, J. G. "Concept of Tubular Jo1nt Design." Journal of the Structural D17,. ASCE, Apr11 1964.

22. Bourkamp, J. G. "Tubular Jo1nt Des1gn." AISC Eng1neering Journal, July 1965, p. 88.

23. Bouwkamp, J, G. "Design of Tubular Joints with Gusset Plates." C1vil Eng. In the Oceans, ASCE, San Francisco, Sept. 6-8, 1967.

24. Brayton, W. C. "Recent Developments in Shipyard Welding." Marine Technology, July 1975, pp. 243253. New York: The Soclety of Naval Architects and Marine Engineers. 
25. Evans, J. Harvey, and Adamchak, John C. Ocean Eng1neering structures. Cambridge, Mass." The M.I.T. Press, 1972 .

26. Murphy, Lawrence M., and Skinrood, Alan C. "Coming: Solar Power Plants." Mechanical Engineerlng. November 1976, pp. 26-32. New York: American Soclety of Mechanical Englneers.

27. Tiedemann, H. M. "Shortcomings of offshore Subsurface Engineering Inspections." Marine Technology, January 1974, pp. 19-30. New York: The Soclety of Naval Architects and Marine Engineers.

28. Tausch, J. H., and Brannan, H. F. Some Economic Considerations in the Design and Selection of Shipboard Gantry cranes (Bridge Type). New York Metropolitan Section SNAME, February 1963 meeting. 


\section{APPENDIX}

\section{CALCULATION OF SHEAR AND TENSION FORCES APPLIED TO TUBULAR CONNECTIONS}

These computations are intended to demonstrate that the proposed connections can be analyzed according to structural principles and also 111 conform to the current requirements of regulatory bodies such as the AISC.

F1gure 12 shows a tension member connected to a vertical tubular leg of a structural frame. The rotation diagram (F1gure 13) shows the relationship of the load on the tension member to the bolted connection. Due to symmetry, only half the flange will be considered. In connections that bolt to flat surfaces, for instance the vertical flange of an H-column, the $X$ component would produce tension in the bolts and the $Y$ component would be resisted by the bolt shear. For the tubular connection under consideration, the $X$ component is resisted by the bolts in the plane A-B. This load produces tension in the bolts and is shown as $R$ in the load rotation diagram, Figure 13.

To 1llustrates $R$ is obtained from the angle of rotation Ph1 (ф), the angular amount the flange bolts are rotated from the plane of the tension member. This angle is indicated in both Figure 12 and Figure 13. 


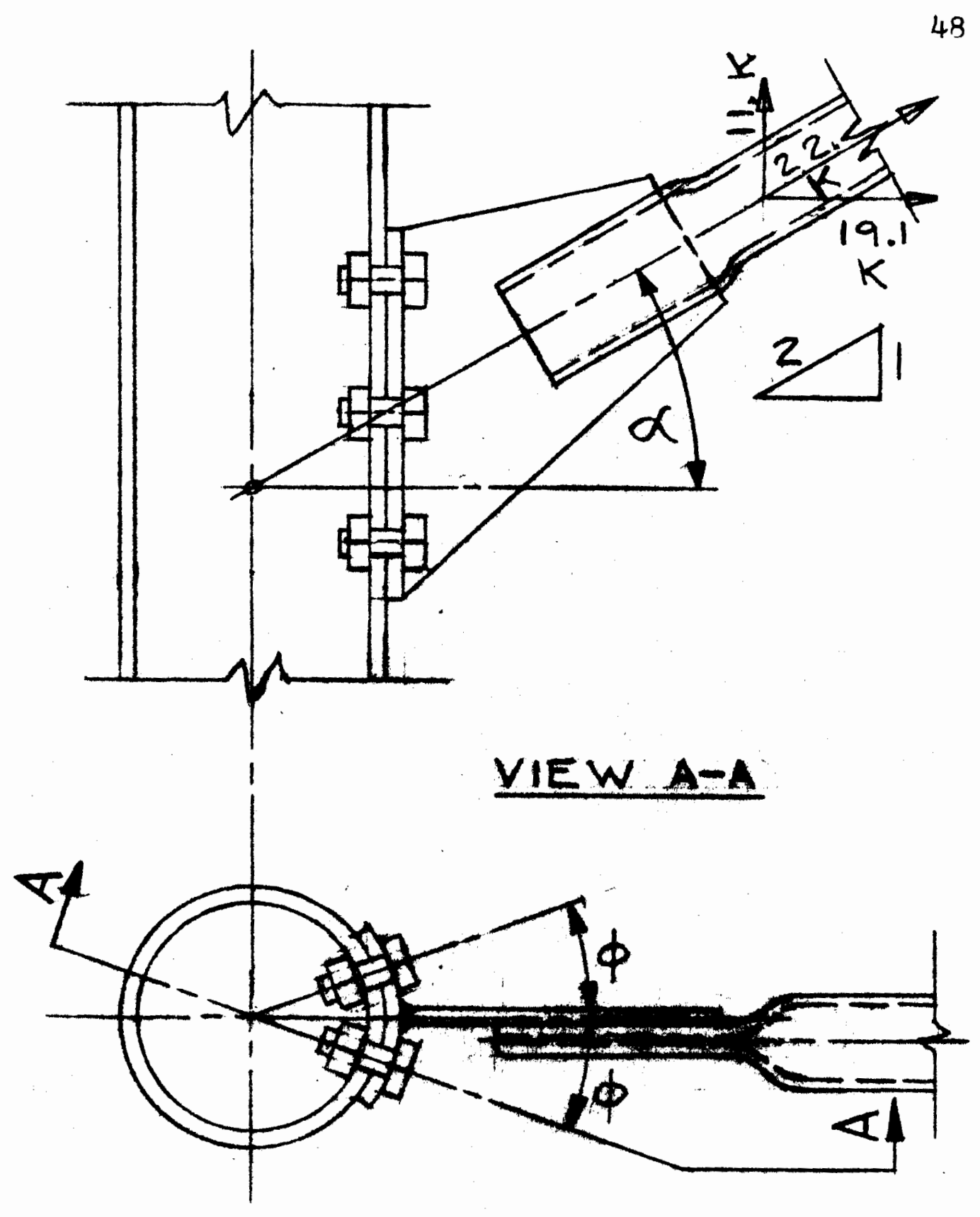

F1gure 12. Tension member with T-bracket. 


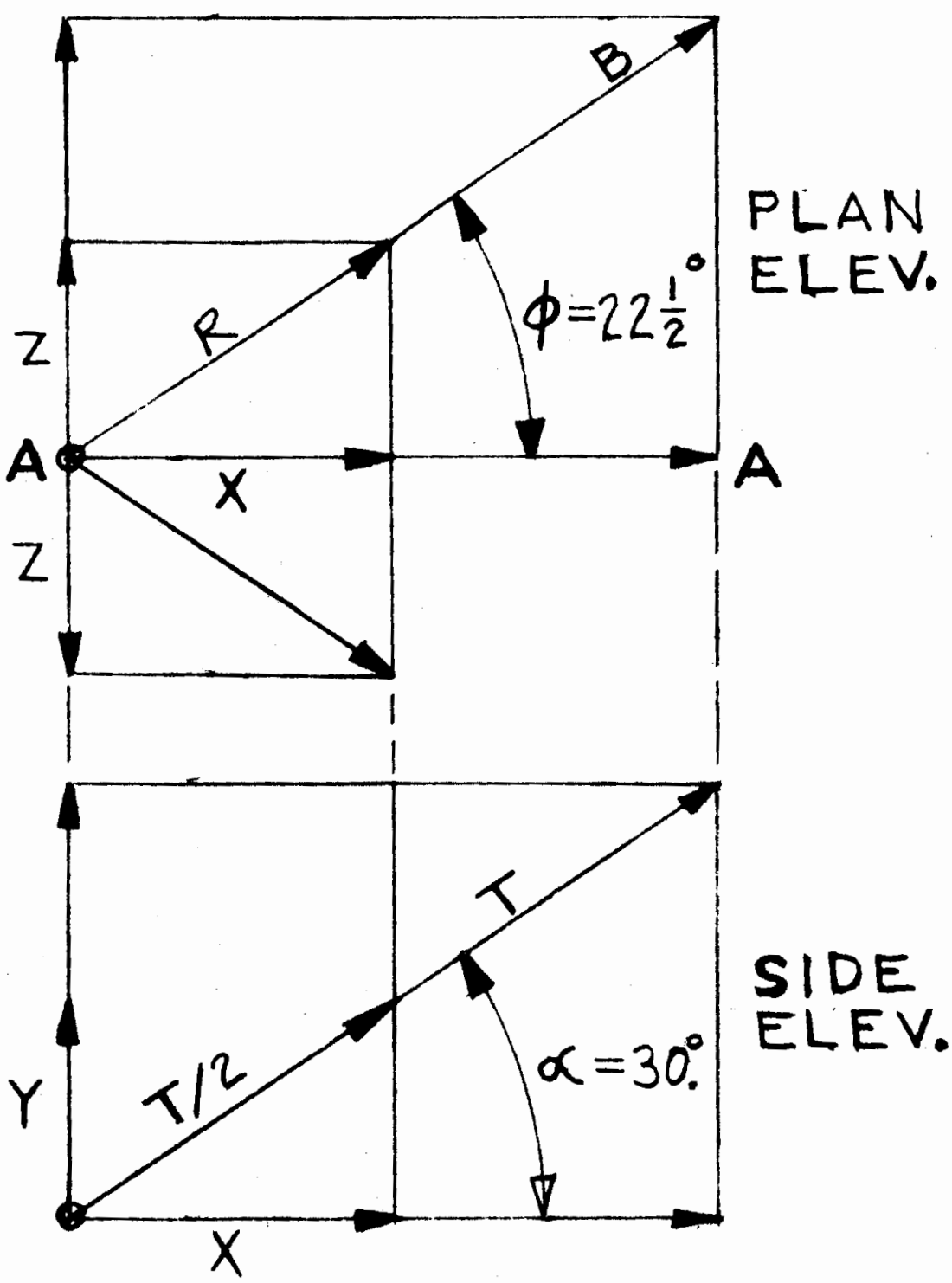

Figure 13. Load rotation diagram. Loads due to thrust and moment in plane $\mathrm{A}-\mathrm{A}$ are rotated into plane $A-B$ as indicated above. 
In both figures the applied tension is specifled as 22 kips and

$$
\begin{aligned}
& T=\text { Member tension, k1ps } \\
& X=\text { Normal tension, k1ps } \\
& Y=\text { Shear component, k1ps } \\
& Z=\text { Bracket balanced component, k1ps } \\
& R=\text { In-plane bolt tension, k1ps } \\
& \text { Half flange load }=T / 2=22.0 / 2=11.0 \mathrm{klps} \\
& X=T / 2 \cos \alpha=11.0 \times 0.8666 \phi=9.53 \mathrm{klps} \\
& Y=T / 2 \sin \alpha=11.0 \times 0.500=5.50 \mathrm{klps} \\
& \mathrm{R}=\frac{X}{\cos \phi}=\frac{9.53}{0.9239}=10.30 \mathrm{k} 1 \mathrm{ps}
\end{aligned}
$$

In the calculation to follow the tubular connection w11l be investigated both as a bearing-type connection and also as a friction-type connection. Light frame construction is assumed. The tension member and the T-bracket are connected to the tubular column with $\$ 1 \times 1 / 2$ inch $A 325$ high-strength bolts. AISC spec1fications will govern. Can the design provided resist the applied load under the above code?

The T-Bracket $8 \mathrm{~s}$ a Bear1ng-Type Connection

The shearing stress is given as $f_{v}$, and $A_{b}$ is the nominal bolt area of the fastener.

$$
r_{v}=\frac{Y}{(3)^{\left(A_{b}\right)}}=\frac{5.50}{(3) \frac{504}{(0.1964)}}=\frac{5.50}{0.588}=9.35 \mathrm{ks}
$$


The AISC Manual (10) on p. 5-193, Table 2, gives as the allowable working stress for a bearlng-type connection, threads excluded, 22,000 psi. On p. 5-23 of the Manual, Section 1.6.3 Shear and Tension, the following statement is mades

Rivets and bolts subject to combined shear and tension shall be so proportioned that the tension stress, in kips per square inch, produced by forces applied to the connected parts, shall not exceed the following:

For $A 325$ and $A 449$ bolts

in bearing-type foints $F_{t}=50.0-1.6 f_{v} \leqslant 40.0$

Allowable, $F_{t}=50.0-1.6(9.35)=50.0-14.94=35.05 \mathrm{ks} 1$

$<40 \mathrm{ks}$

Table 2, p. 5-193, of the Manual gives as the allowable applied tension for ASTM A325 bolts 40,000 psi max1mum.

Actual, $f_{t}=\frac{R}{(3)^{(}\left(A_{b}\right)}=\frac{10.30}{(3)(0.1964)}=\frac{10.30}{0.588}=17.60 \mathrm{ks} 1$ $<35.05 \mathrm{ks} 1$

This is considered satisfactory.

The T-Bracket as a Friction-Type Connection

The computed tensile stress is given as $f_{t}$.

$$
\begin{array}{r}
f_{t}=\frac{R}{(3)\left(A_{b}\right)}=\frac{10.30}{(3)(0.1964)}=\frac{10.30}{0.588}=17.60 \mathrm{ks} 1 \\
\end{array}
$$

In regard to the irlction-type joint the AISC Manual has the following statement on p. 5-24:

For bolts used in friction-type joints, the shear stress allowed in Sect. 1.5 .2 shall be reduced so that: 
Por $A 325$ and 4449 bolts $F_{\nabla} \leqslant 15.0\left(1.0-I_{t} A_{b} / T_{b}\right)$ where $f_{t}$ is the average tensile stress due to a direct load applied to all of the bolts in a connection and $\mathrm{T}_{\mathrm{b}} 1 \mathrm{~s}$ the specified protension load of the bolt.

In the calculation here presenteds

$r_{t}=17.60 \mathrm{ks} 1$

$T_{b}=12,0001 \mathrm{bs} .=12.0 \mathrm{k} 1 \mathrm{ps}$

$A_{b}=0.19641 \mathrm{n} .^{2}$

Allowable, $F_{v}=15 .\left(1.0-\frac{12.6 \times 0.1964}{12.0}\right)$

$$
\begin{aligned}
& =15 .(1.0-0.287) \\
F_{\nabla} & =15 . \times 0.713=10.70 \mathrm{ks1}
\end{aligned}
$$

Actual, $f_{v}=\frac{5.50}{0.588}=9.36 \mathrm{ks1}$

$<10.70 \mathrm{ks} 1$

The design is therefore considered satisfactory as a friction-type connection.

Other examples could be presented, but the above figures w11 show the application of structural codes and methods of computation. 


\section{VITA}

John H. Tausch recelved the degree of Bachelor of Sclence in Mechanfcal Engineering from Northeastern University in 1940. His early experience was as a machine and tool designer in the rubber, crane, and machine tool flelds; but the major part of his work has been in the shipbuilding and construction industries. As a mechanical engineer he has designed equipment for the process industry, dredges, cranes, and the powering of industrial equipment. His marine engineering experience includes the design and development of propelling machinery, ship structure, steering equipment, hydraulic drives, cargo handling equipment, etc. He is a registered engineer in Massachusetts, Maine, and Oregon; and a member of the Soclety of Naval Architects and Marine Engineers (SNAME), National Soclety of Professional Engineers (NSPE), and Professional Englneers of Oregon (PEO). 